УДК 351. 142:005.25

\title{
ОСНОВНІ ПОЛОЖЕННЯ ЩОДО ЛОГІСТИЧНОГО ЗАБЕЗПЕЧЕННЯ НАЦІОНАЛЬНОЇ ГВАРДІЇ УКРАЇНИ
}

\author{
Бондаренко О. Г., к.н.дерэс.упр., доцент, полковник, докторант, \\ Товма Л.Ф., к.т.н., доцент, капітан, \\ Нестеренко Р.В., ст. викладач, майор \\ Касім О.Г., ст. викладач, полковник запасу (НА НГУ)
}

У статті обтрунтовані основні напрямки та положення щодо логістичного забезпечення Національної гвардії України. Запропоновано авторське визначення, основні складові, принципи та функції логістичного забезпечення Національної гвардії України в сучасних умовах. Досліджено, щуо логістичне забезпечення Начіональної гвардії України має базуватися на принципах, які узгоджуються із вітчизняними та міжнародними стандартами безпеки та оборони.

Ключові слова: логістичне забезпечення, Національна гвардія Украӥни, складові логістичного забезпечення, функції логістичного забезпечення, принципи логістичного забезпечення, система.

\section{ОСНОВНЫЕ ПОЛОЖЕНИЯ ПО ЛОГИСТИЧЕСКОМУ ОБЕСПЕЧЕНИЮ НАЦИОНАЛЬНОЙ ГВАРДИИ УКРАИНЫ}

\author{
Бондаренко А. Г., к.н.гос.упр., доцент, полковник, докторант, \\ Товма Л.Ф., к.т.н., доцент, капитан, \\ Нестеренко Р.В., ст. преподаватель, майор, \\ Касим А.Г., ст. преподаватель, полковник запаса (НА НГУ)
}

В статье обоснованы основные направления и положения относительно логистического обеспечения Национальной гвардии Украины. Предложено авторское определение, основные составляющие, принщипы и функиии логистического обеспечения Начиональной гвардии Украины в современных условиях. Доказано, что логистическое обеспечение Наџиональной гвардии Украинь должно базироваться на принципах, которые согласуются с отечественными и международными стандартами безопасности и обороньл.

Ключевые слова: логистическое обеспечение, Национальная гвардия Украины, составляющие логистического обеспечения, функции логистического обеспечения, принципы логистического обеспечения, система.

( ) Бондаренко О.Г., Товма Л.Ф., Нестеренко Р.В., Каміс О.Г.

Вісник економіки транспорту і промисловості № 61, 2018 


\title{
BASIC PROVISIONS ON LOGISTIC SECURITY OF THE NATIONAL GUARDS OF UKRAINE
}

\author{
Bondarenko A.G., Ph.D. in Public Administration, Associate Professor, Colonel, \\ Doctoral candidate, \\ Tovma L.F., Candidate of Technical Sciences, Captain, Associate Professor, \\ Nesterenko R.V., Senior Lecturer, Major, \\ Kasim A. G., Senior Lecturer, Colonel of the Reserve (National Guard of Ukraine)
}

Modern challenges and threats to the state security of Ukraine require the creation of effective mechanisms for fighting and counteracting such threats, in particular, the urgent reformation of security and defense sectors, including the National Guard of Ukraine, as one of the key components of this sector, based on EU principles and standards and NATO.

The logistic support of the National Guard of Ukraine, as well as the Ukrainian armed forces, should include: logistic support planning, determination of material and technical support needs, development of technical tasks for the production of armaments and military equipment and logistical equipment for the specific needs of the National Guard of Ukraine, procurement, supply, storage, repair, maintenance, control of operation (use), sale, disposal and disposal of surplus weapons and military equipment logistics and logistics, planning and implementation of military transportation by all available means of transport, quartering of troops, procurement of works and services, bath-laundry and trade and household services, catering, procurement or construction, maintenance, operation of military infrastructure objects .

The logistic support of the National Guard of Ukraine must conform to the following principles consistent with NATO's legislative logistical support, namely: priority; sufficiency efficiency; Flexibility; Transparency; coordination; responsibility; cooperation; interoperability; sustainability, etc.

The logistic support system of the National Guard of Ukraine should be divided into operational, operational-tactical and tactical levels, between which there is a clear distribution of functions and powers for the organization of logistic support of the National Guard of Ukraine. Therefore, it is advisable to take into account the above provisions when developing the relevant guidance documents on the creation of a logistics system for the National Guard of Ukraine.

Keywords: logistic support, National Guard of Ukraine, logistics components, logistic support functions, logistic support principles, system.

Постановка проблеми та її України, секретар РНБО, міністр зв'язки 3 науковими чи практичними внутрішніх справ, командувач НГУ, завданнями. Сучасні виклики i загрози керівники інших силових міністерств та державній безпеці України вимагають відомств неодноразово відмічали основні створення ефективних механізмів три складові такого реформування: боротьби та протидії таким загрозам, реформування систем управління, зокрема, невідкладного реформування підготовки та забезпечення. Так, Указом формувань сектору безпеки i оборони Президента України від 14 березня 2016 (СБО), у тому числі Національної гвардії року № 92/2016 затверджена Концепція України (НГУ) як однієї із основних розвитку сектору безпеки і оборони [1], a складових сектору, на основі принципів та розпорядженням Кабінету Міністрів стандартів ЄС i НАТО. Президент України від 01.02.2017 № 100-p 
затверджена Концепція розвитку НГУ на період до 2020 року [2]. У вказаних документах, серед інших, основною із причин виникнення проблем зазначено недосконалість системи логістики.

Досягнення мети Концепції розвитку НГУ до 2020 року реалізується шляхом виконання комплексу завдань i заходів серед яких будуть особливо цікавити такі: оснащення військових частин та підрозділів Національної гвардії новітнім та модернізованим озброєнням, військовою та спеціальною технікою, спеціальними засобами та обладнанням 3 урахуванням їх потреб; забезпечення розвитку системи бойової та спеціальної підготовки; удосконалення системи управління Національною гвардією; реформування системи логістики (технічного та тилового забезпечення) відповідно до зростаючих потреб Національної гвардії; удосконалення системи медичного забезпечення, реабілітації та психологічної підтримки особового складу Національної гвардії; відновлення інфраструктури Національної гвардії та військових містечок, розгортання автономних військових баз 3 відповідною інфраструктурою для розташування військових частин та соціально-побутових об'єктів для військовослужбовців та членів їх сімей; удосконалення правових засад функціонування Національної гвардії.

Отже, центральним елементом розвитку та реформування НГУ $\epsilon$ удосконалення системи логістичного забезпечення (ЛЗ) з'єднань, військових частин та підрозділів яке, у свою чергу, потребує наукового підгрунтя.

Аналіз останніх досліджень i публікацій та виділення невирішених частин загальної проблеми. Слід зазначити, що як НГУ та і Збройні Сили України (ЗСУ) перебувають сьогодні у стані реформування за стандартами НАТО. Так, указом Президента України від 06.06.2016 № 240/2016 введено у дію Стратегічний оборонний бюлетень [3], який $\epsilon$ дорожньою картою оборонної реформи 3 визначенням шляхів іiі впровадження на засадах i принципах, якими керуються держави-члени НАТО. На виконання вимог вказаного документу Міністерством оборони України (МОУ) розроблено та прийнято наказ МОУ від 11.10.2016 № 522 «Основні положення логістичного забезпечення Збройних сил України» [4]. Цим документом вводиться у вжиток поняття «логістичне забезпечення», яке замінює собою такі поняття як «тилове i технічне забезпечення», «матеріально-технічне забезпечення», «матеріальне забезпечення».

Незважаючи на те, що тільки нещодавно офіційно прийнято в Україні у вжиток поняття «логістичне забезпечення» цілий ряд вітчизняних вчених достатньо активно опікуються проблемами вказаного виду забезпечення. Так, автори у [5] проводили воєнноісторичний i семантичний аналізи поняття “логістика" в різних його аспектах. Зокрема, вони дійшли висновку, що у той період (у 2006 році) впровадження у вітчизняну воєнну науку поняття “система логістики” було б передчасним i не узгоджувалось зі стандартами НАТО. Автор у [6] опікувався проблемами державного управління реформуванням системи тилового (логістичного) забезпечення ЗСУ у контексті досвіду країн НАТО. Автори у [7] обгрунтовують напрямки досліджень проблем управління логістичним забезпеченням спільних дій формувань Сектору безпеки і оборони при кризових ситуаціях, що загрожують державній безпеці України. На наш погляд, особливо цікаво та корисно у [8] автори аналізують зміст основних термінів у сфері логістичного забезпечення військових формувань: проводять порівняння вітчизняної термінології у сфері логістичного забезпечення військових формувань в контексті іiі відповідності стандартам НАТО, наводять зміст поняття 
"Об'єднана логістика" як функції забезпечення бойових дій на оперативному та на тактичному рівнях у доктринальних документах країн-членів НАТО, а також, відповідно, роблять висновок про принципіальну необхідність інтегрування сил та засобів логістики суб'єктів сектору безпеки і оборони в інтересах дій об'єднаних (міжвідомчих) угруповань військ (сил) під час реагування на наявні та потенційні загрози.

Отже метою роботи є дослідження обгрунтування основних напрямків та положень щодо логістичного забезпечення Національної гвардії України.

Виклад основного матеріалу дослідження. Відповідно [3], перед НГУ постає питання реформування системи тилового забезпечення і перетворення iï у систему логістичного забезпечення відповідно до стандартів НАТО. Виходячи iз вище викладеного, на переконання авторів, доцільно розробити керівний документ, який би визначав основні положення логістичного забезпечення НГУ. Саме тому, на нашу думку, для вказаного обгрунтування слід застосовувати основні положення щодо ЛЗ у ЗСУ. У [4] дається таке визначення ЛЗ ЗСУ: логістичне забезпечення - це комплекс взаємопов'язаних заходів, який забезпечує діяльність Збройних Сил у мирний та воєнний час.

У довіднику 3 тилового забезпечення НАТО, який було перекладено російською мовою у 2012 році, під поняттям "logistic supply" (вказане поняття українською мовою прийнято перекладати саме логістичне забезпечення) розуміють наступним чином. “3 точки зору життєвого циклу тилове забезпечення - це сполучна ланка між розгорнутими військами (силами) та промисловою базою, що виробляє озброєння і військове майно, необхідні військам для виконання поставленого перед ними завдання. У НАТО дається таке визначення тилового забезпечення. У широкому сенсі тилове забезпечення - це наука планування та здійснення руху i забезпечення діяльності військ (сил). Цей термін застосовується до аспектів військових операцій, пов'язаних 3 наступними видами діяльності: проектування, розробка, закупівля, зберігання, транспортування, розподіл, догляд, евакуація та утилізація військового майна; транспортування особового складу; закупівля або будівництво, технічне обслуговування, експлуатація та реалізація об'єктів; придбання чи надання послуг; медичної служби. Дане визначення охоплює широке коло обов'язків у різних сферах діяльності, яка здійснюється в НАТО. Якщо розглядати тилове забезпечення як діяльність по створенню запасів і коштів, a також щодо забезпечення бойової стійкості систем зброї і військ (сил), то можна виділити три важливих аспекти тилового забезпечення, що відображають весь життєвий цикл тилових ресурсів: виробництво, технічне обслуговування в процесі експлуатації та споживання (витрати)" [9].

На погляд авторів, наведене у [4] визначення ЛЗ ЗСУ сформульовано у занадто загальному вигляді і не розкриває специфіку та значення даного виду всебічного забезпечення військ. Враховуючи вище сказано, нами пропонується таке визначення ЛЗ НГУ: логістичне забезпечення НГУ - це широкий комплекс взаємопов'язаних заходів, пов'язаних із плануванням, контролем та управлінням постачанням, транспортуванням, зберіганням та іншими матеріальними i нематеріальними операціями, у тому числі щодо передавання, зберігання i обробки відповідної інформації, які здійснюються у процесі забезпечення службово-бойової діяльності Національної гвардії України у мирний та воєнний час.

ЛЗ НГУ, як і ЗСУ має включати: планування ЛЗ, визначення потреб у МТЗ, розроблення технічних завдань на виробництво озброєння і військової 
техніки та матеріально-технічних засобів (OBT та МТ3) для специфічних потреб НГУ, їх закупівлю, постачання, зберігання, ремонт, технічне обслуговування, контроль експлуатації (використання), реалізації, списання та утилізації надлишкового ОВТ та МТ3, планування та здійснення військових перевезень у НГУ усіма наявними видами транспорту, розквартирування військ, закупівлю робіт та послуг, лазне-пральне та торговельно-побутове обслуговування, організацію харчування, закупівлю або будівництво, технічне обслуговування, експлуатацію об'єктів військової інфраструктури.

Л3 НГУ повинне відповідати наступним вимогам: відповідність нормативно-правовій базі щодо організації Л3 НГУ, Збройних Сил та інших військових формувань держави; централізована організація планування ЛЗ, військових перевезень НГУ усіма наявними видами транспорту та підвезення МТ3 автомобільним транспортом; модульний та територіальний принципи побудови інфраструктури логістики НГУ [10]; баланс між ефективністю ЛЗ та досягненням максимальної економії державних коштів; чітка та прозора система управління Л3; забезпечення раціонального розподілу, своєчасного накопичення, належного зберігання непорушних та військових запасів МТЗ та можливість здійснювати їх своєчасний перерозподіл (оперативний маневр); ефективність та прозорість усіх процесів у сфері закупівель МТЗ для потреб НГУ, а також у ланках постачання (на складах, у транспорті) через упровадження сучасних технологій та автоматизацію процесів; можливість виконувати весь комплекс завдань із ЛЗ угруповань НГУ у мирний та воєнний час i здійснювати швидку перебудову (адаптацію) відповідно до змін обстановки; своєчасний та якісний ремонт OВТ, списання (утилізація, реалізація) МТ3; відповідність основним принципам керівництва ЛЗ збройних сил країн членів НАТО, а також схожих за завданнями формувань інших держав; взаємосумісність із системами логістики всіх складових сил сектору безпеки i оборони та максимальне наближення до логістичної складової суб'єктів національної економіки України; наявність системи підвищення кваліфікації особового складу, задіяного для виконання завдань ЛЗ НГУ.

ЛЗ НГУ повинне відповідати таким принципам, що узгоджуються 3 законодавчими актами 3 питань національної безпеки та оборони України i зі стандартами ЛЗ НАТО:

- пріоритетності - організація надійного, повного та своєчасного забезпечення НГУ необхідними ОВТ та MT3;

- достатності - своєчасне забезпечення НГУ необхідними ОВТ та МТЗ відповідно до визначених потреб;

- ефективності - максимально ефективне використання отриманих ОВТ, МТЗ та послуг;

- гнучкості - дії на випереджання зі здатністю до адаптації та швидкого реагування на обставини, що змінюються;

$$
\text { - прозорості _ обмін }
$$

достовірною інформацією щодо потреб та наявності запасів ОВТ та МТЗ по службах забезпечення всіх рівнів, з урахуванням ступенів доступу до неї (забезпечення захисту конфіденційної інформації);

- координації - взаємодія всіх складових системи логістики НГУ між собою та з системами логістики складових сектору безпеки i оборони 3 метою ефективного функціонування системи взагалі, а також 3 органами іноземних держав, міжнародними організаціями та збройними силами та правоохоронними формуваннями інших держав на підставі укладених міжнародних договорів України, у тому числі із країнами членами НАТО; 
- відповідальності - Головне управління Національної гвардії України (ГУ НГУ), відповідно до повноважень, визначених законодавством України, несуть повну відповідальність за ЛЗ службово-бойової діяльності (СБД) НГУ у мирний та воєнний час. Органи управління логістики всіх рівнів у своїй діяльності повинні суворо дотримуватися наданих повноважень та нести відповідальність за своєчасне виконання визначених завдань;

- співробітництва

співробітництво між НГУ та іншими формуваннями СБО, центральними та місцевими органам виконавчої влади, органами місцевого самоврядування, державними підприємствами обороннопромислового комплексу, іншими підприємствами національної економіки України, а також 3 органами іноземних держав, міжнародними організаціями та збройними та правоохоронними формуваннями інших держав на підставі укладених міжнародних договорів України в питаннях ЛЗ повинно бути спрямоване на ефективне та своєчасне задоволення потреб НГУ;

- функціональної сумісності - ЛЗ НГУ має за мету досягнення повної функціональної сумісності із ЛЗ ЗСУ, інших формувань СБО, військовими та правоохоронними формуваннями інших держав-партерів (насамперед країн-членів НАТО), що надасть можливість інтеграції систем під час виконання сумісних операцій, а також можливість застосування окремих зразків ОВТ та номенклатури МТЗ країн - членів НАТО (країн - партнерів) для задоволення потреб забезпечення НГУ;

- стійкості - організація ЛЗ

повинна передбачати заходи, які спрямовані на мінімізацію втрат виділених ресурсів від впливу певних факторів (зовнішніх i внутрішніх, позитивних i негативних), а у ході службово-бойових та бойових дій (СБ та БД) - від впливу противника.

Загальна організація та управління ЛЗ НГУ здійснюється ГУ НГУ, для здійснення чого необхідно створити дієву систему логістики у НГУ, яка представлятиме з себе сукупність органів управління, сил і засобів ЛЗ, призначених для виконання завдань ЛЗ НГУ, між якими існують зв'язок та взаємодія. Схематично система логістики представлена на рис. 1.

Система ЛЗ НГУ має поділятися на оперативний, оперативно-тактичний та тактичний рівні, між якими існує чіткий розподіл функцій та повноважень щодо організації ЛЗ НГУ.

Органи управління Л3 - це управління, відділи (відділення), служби та інші постійні та тимчасово створювані органи, які призначені для виконання функцій управління Л3 [11]. Сили і засоби ЛЗ - це установи, бази зберігання i забезпечення, склади, військові частини (підрозділи) 3 визначеними обсягами запасів матеріально-технічних засобів, військові частини (підрозділи) підвезення (автомобільні), ремонту та евакуації озброєння та військової техніки.

На оперативному рівні - структурні підрозділи ГУ НГУ із завданням щодо організації розроблення технічних завдань на виробництво ОВТ та МТЗ, їх закупівлі і постачання, надання послуг та їх фінансування в обсягах, необхідних для ефективного виконання НГУ покладених на неї завдань; організації Л3 з'єднань (військових частин, підрозділів) у їх повсякденній діяльності, під час проведення заходів бойової підготовки, виконання заходів СБД, під час відмобілізування, підготовки та ведення СБ та БД, відновлення боєздатності військ, отримання, накопичення, обліку, зберігання, постачання та поповнення запасів МТ3. 


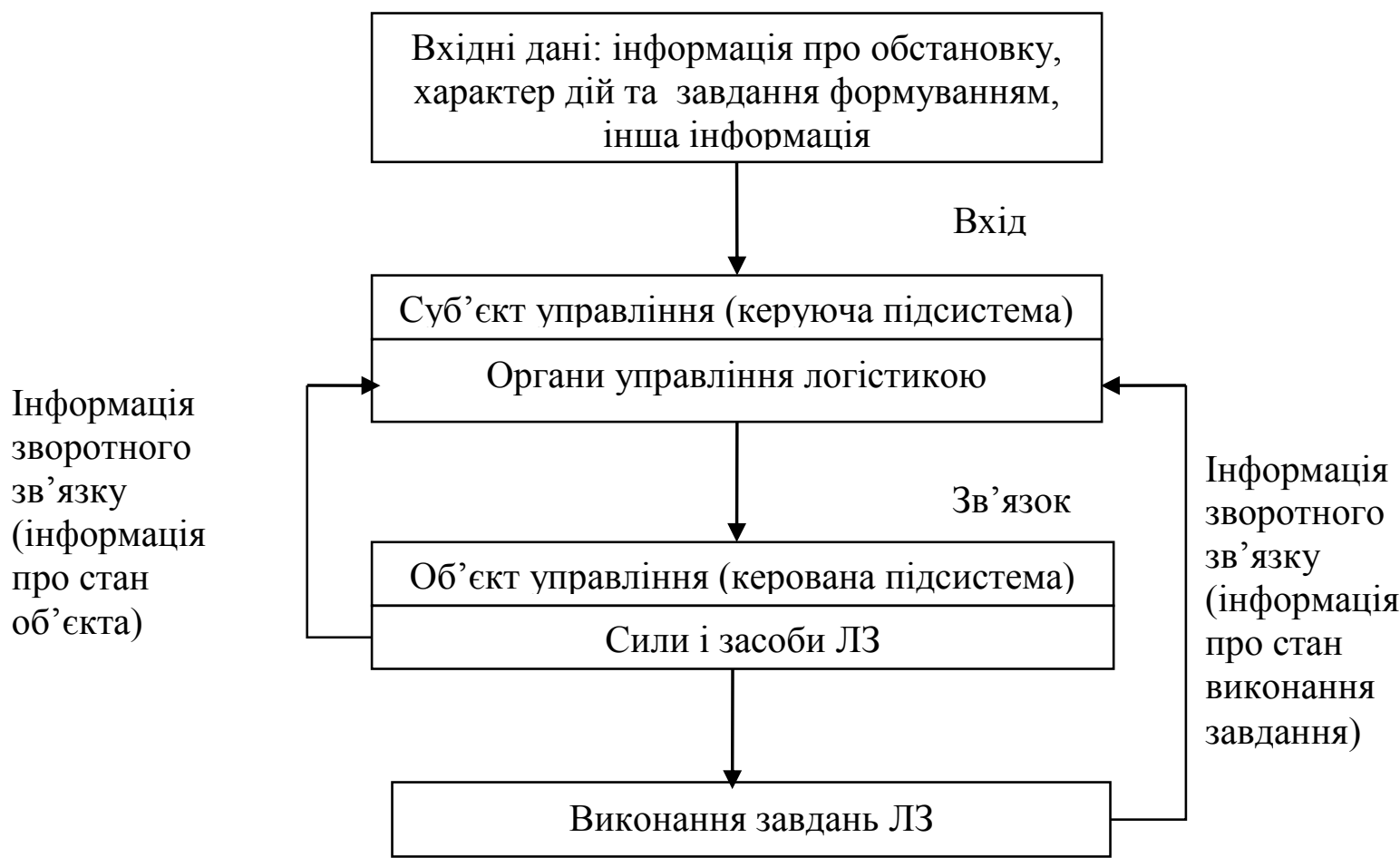

Рис. 1. Схема системи логістики НГУ

На оперативно-тактичному рівні служби логістики територіальних управлінь оперативно-територіальних об'єднань (ОТО) НГУ з підпорядкованими силами та засобами ЛЗ із завданнями щодо планування та організації ЛЗ підпорядкованих з'єднань та військових частин у їх повсякденній діяльності, під час проведення заходів бойової підготовки, СБД, відмобілізування та приведення у бойову готовність, підготовки та ведення СБ та БД, відновлення боєздатності військ;

На тактичному рівні - служби логістики військових частин та з'єднань НГУ 3 підпорядкованими силами та засобами ЛЗ, призначені для вирішення завдань ЛЗ з'єднань (військових частин, підрозділів) у їх повсякденній діяльності, під час заходів бойової підготовки, СБД, відмобілізування та приведення у бойову готовність, підготовки та ведення СБ то БД, відновлення боєздатності військових частин (підрозділів).
3 метою досягнення максимальної функціональної сумісності 3 системою логістики НАТО під час побудови системи логістики НГУ при веденні СБ та БД передбачається використовувати принцип побудови рубежів ЛЗ.

Перший рубіж ЛЗ призначений для виконання завдань ЛЗ військових частин, які безпосередньо ведуть СБ та БД. Для виконання завдань на першому рубежі ЛЗ можуть залучатися сили і засоби другого рубежу ЛЗ.

Другий рубіж ЛЗ розгортається на безпечній відстані від лінії зіткнення 3 противником (району виконання СБЗ) i призначений для виконання завдань Л3 усіх військ в межі відповідальності ОТО. Для виконання завдань на другому рубежі ЛЗ можуть залучатися сили i засоби третього рубежу ЛЗ.

Третій рубіж ЛЗ знаходиться поза межами зони відповідальності ОТО i призначений для виконання завдань із забезпечення НГУ ОВТ та МТЗ, роботами 
та послугами відповідно до визначених потреб та їх підвезення на другий рубіж Л3 для забезпечення визначених угруповань військ, а за необхідності - i на перший рубіж ЛЗ.

До функцій ЛЗ НГУ повинні відноситися:

- постачання та обслуговування;

- технічне обслуговування і

ремонт;

- перевезення і транспортування; забезпечення;

- інженерно-інфраструктурне

- здійснення постачання товарів, робіт і послуг для забезпечення потреб НГУ;

- аудит та інспекція;

- підготовка та навчання;

- стандартизація й сфері Л3;

- управління інформацією ЛЗ

(інформаційної логістики);

- медичне забезпечення;

- військово-цивільне

співробітництво (суміжна функція).

Основні риси, які характеризують схожості та відмінності тилового та логістичного забезпечення наведені у таблиці 1.

Основні риси тилового та логістичного забезпечення НГУ

\begin{tabular}{|c|c|c|c|}
\hline № & \multirow[t]{2}{*}{ Найменування риси } & \multicolumn{2}{|c|}{ Сутність риси } \\
\hline 3.П. & & Тилове забезпечення & логістичне забезпечення \\
\hline 1 & 2 & 3 & 4 \\
\hline 1. & Визначення & $\begin{array}{lcr}\text { Комплекс } & \text { заходів, } \\
\text { здійснюються } & 3 & \text { які } \\
\text { задоволення } & \text { матеріальних, } \\
\text { транспортних, побутових та } \\
\text { інших потреб військ (сил) для } \\
\text { підтримання їх у боєздатному } \\
\text { стані та створення сприятливих } \\
\text { умов для виконання покладених } \\
\text { на них завдань }\end{array}$ & $\begin{array}{l}\text { Широкий комплекс взаємопов'язаних } \\
\text { заходів, пов’язаних із плануванням, } \\
\text { контролем та управлінням } \\
\text { постачанням, транспортуванням, } \\
\text { зберіганням та іншими матеріальними і } \\
\text { нематеріальними операціями, у тому } \\
\text { числі щодо передавання, зберігання і } \\
\text { обробки відповідної інформації, які } \\
\text { здійснюються у процесі забезпечення } \\
\text { службово-бойової діяльності НГУ у } \\
\text { мирний та воєнний час }\end{array}$ \\
\hline & Види, складові & $\begin{array}{l}\text { - матеріальне, } \\
\text { - транспортне, } \\
\text { - медичне, } \\
\text { - квартирно-експлуатаційне, } \\
\text { - ветеринарне, } \\
\text { - торгівельно-побутове, } \\
\text { - інженерно-аеродромне; } \\
\text { - аеродромно-технічне } \\
\text { забезпечення; } \\
\text { - фінансове забезпечення (в } \\
\text { особливий період). }\end{array}$ & $\begin{array}{l}\text { - планування Л3, визначення потреб } \\
\text { у МТЗ, розроблення технічних завдань } \\
\text { на виробництво ОВТ та МТЗ для } \\
\text { специфічних потреб НГУ, їх закупівлю, } \\
\text { постачання, зберігання, ремонт; } \\
\text { - технічне обслуговування, контроль } \\
\text { експлуатації (використання), реалізації, } \\
\text { списання та утилізації надлишкового } \\
\text { ОВТ та МТЗ; } \\
\text { - планування та здійснення } \\
\text { військових перевезень у НГУ усіма } \\
\text { наявними видами транспорту; } \\
\text { - розквартирування військ; } \\
\text { - закупівлю робіт та послуг, лазне- } \\
\text { пральне та торговельно-побутове } \\
\text { обслуговування; }\end{array}$ \\
\hline & & & $\begin{array}{l}\text { - } \text { Організацію харчування; } \\
\text { - } \text { закупівлю або будівництво, технічне } \\
\text { обслуговування, експлуатацію об’єктів } \\
\text { військової інфраструктури. }\end{array}$ \\
\hline
\end{tabular}




\begin{tabular}{|c|c|c|c|}
\hline & & & 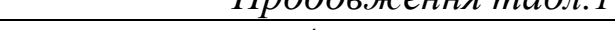 \\
\hline 1 & 2 & 3 & 4 \\
\hline 2. & Рівні & $\begin{array}{l}\text { Стратегічний тил } \\
\text { Оперативний тил } \\
\text { Військовий тил }\end{array}$ & $\begin{array}{l}\text { Оперативний рівень логістики } \\
\text { Оперативн-тактичний рівень логістики } \\
\text { Тактичний рівень логістики }\end{array}$ \\
\hline 3. & Рубежі & -- & $\begin{array}{l}\text { Перший рубіж ЛЗ призначений для } \\
\text { виконання завдань Л3 військових } \\
\text { частин, які безпосередньо ведуть СБ та } \\
\text { БД. Другий рубіж ЛЗ розгортається на } \\
\text { безпечній відстані від лінії зіткнення } \\
\text { противником (району виконання СБЗ) і } \\
\text { призначений для виконання завдань Л3 } \\
\text { усіх військ в межі відповідальності } \\
\text { ОТО. } \\
\text { Третій рубіж ЛЗ знаходиться поза } \\
\text { межами зони відповідальності ОТО і } \\
\text { призначений для виконання завдань із } \\
\text { забезпечення НГУ ОВТ та МТЗ, } \\
\text { роботами та послугами відповідно до } \\
\text { визначених потреб та іх підвезення на } \\
\text { другий рубіж ЛЗ для забезпечення } \\
\text { визначених угруповань військ, а за } \\
\text { необхідності-і на перший рубіж ЛЗ. }\end{array}$ \\
\hline & $\begin{array}{ll}\text { Класи } & \text { постачання } \\
\text { МТЗ }\end{array}$ & $\begin{array}{l}\text { 1) озброєння, бойова та інша } \\
\text { техніка, боєприпаси, засоби } \\
\text { активної оборони, сигнальні та } \\
\text { освітлювальні патрони; } \\
\text { 2) ПММ; } \\
\text { 3) продовольство та вода; } \\
\text { 4) запасні частини, прилади, } \\
\text { інструменти для ремонту та } \\
\text { технічного обслуговування; } \\
\text { 5) медичне обладнання та } \\
\text { майно; } \\
\text { 6) будівельні та фортифікаційні } \\
\text { матеріали. }\end{array}$ & $\begin{array}{l}\text { 1) продовольство (продукти харчування } \\
\text { та корм), що споживаються особовим } \\
\text { складом та тваринами, для якого } \\
\text { встановлені єдині норми; } \\
\text { 2) предмети постачання, що видаються } \\
\text { за нормами, установленими штатами та } \\
\text { табелями до них (озброєння та зброя, } \\
\text { військова техніка та технічні засоб, } \\
\text { обмундирування та спорядженн, } \\
\text { інструменти, запасні частини тощо); } \\
\text { 3) усі види нафтопродуктів та пально- } \\
\text { мастильних матеріалів, паливо; } \\
\text { 4) предмети постачання, норми видачі } \\
\text { яких не визначені встановленими } \\
\text { штатами та табелями (фортифікаційні та } \\
\text { будівельні матеріали); } \\
\text { 5) різні види ракет, боєприпасів, } \\
\text { вибухових та хімічних речовин. }\end{array}$ \\
\hline
\end{tabular}

Висновки: Таким чином, забезпечення у НГУ представляє собою підсумовуючи вище наведене, автори безперервний та взаємопов'язаний процес дійшли висновку, що логістичне планування та визначення потреб у МТЗ; 
розроблення технічних завдань на виробництво ОВТ та МТЗ для специфічних потреб НГУ, їх закупівлю, постачання, зберігання, ремонт; технічне обслуговування, контроль експлуатації (використання), реалізації, списання та утилізації надлишкового ОВТ та МТ3; планування та здійснення військових перевезень у НГУ усіма наявними видами транспорту; розквартирування військ; закупівлю робіт та послуг, лазне-пральне та торговельно-побутове обслуговування; організацію харчування; закупівлю або будівництво, технічне обслуговування, експлуатацію об'єктів військової інфраструктури. Слід зазначити, що окрім вказаного наказу Міністра оборони [4], інших документів, які б регламентували організацію та управління ЛЗ ЗСУ, НГУ та інших складових СБО в України поки немає.

Таким чином, на погляд авторів, вище вказані положення доцільно врахувати при розробленні відповідних керівних документів щодо створення системи ЛЗ НГУ.

\section{ПЕРЕЛІК ВИКОРИСТАНИХ ДЖЕРЕЛ}

1. Про рішення Ради національної безпеки і оборони України від 4 березня 2016 року "Про Концепцію розвитку сектору безпеки i оборони України" [Електрон. ресурс]: Указ Президента України від 14 березня 2016 року № 92/2016. - Режим доступу: http://www.president.gov.ua/documents/ 922016-19832.

2. Про схвалення Концепції розвитку Національної гвардії на період до 2020 року [Електрон. ресурс]: розпорядженням Кабінету Міністрів України від 01.02.2017 № 100-р. - Режим доступу:

http://zakon3.rada.gov.ua/laws/show/1002017-p/print1459319692354219.

3. Про рішення Ради національної безпеки і оборони України від 20 травня 2016 року "Про Стратегічний оборонний бюлетень України" [Електрон. ресурс]: Указ Президента України від 06 червня 2016 № 240/2016. - Режим доступу: http://www.president.gov.ua/documents/2402 016-20137.

4. Основні положення логістичного забезпечення Збройних сил України [Електрон. ресурс]: наказ МОУ від 11 жовтня 2016 № 522. - Режим доступу: http://www.mil.gov.ua/ministry/normativnopravova-baza/nakazi-ministra-oboroniukraini/nakazi-ministerstva-oboroni-ukrainiza-2016-rik.html.

5. Ролін, І.Ф. Чи є логістика видом забезпечення військ та їх дій? / І.Ф. Ролін, С.М. Вашист, О.В. Гафуров // Честь i закон. - 2003. - № 3. - Х.: ВI ВB МBC України. - С. 41-45.

6. Нагорнічевський, О Державне управління реформуванням системи тилового забезпечення Збройних сил України в контексті досвіду країн НАТО / O. Нагорнічевський // Державне управління та місцеве самоврядування: збірник наук. праць. - 2015. - Вип. 2 (25). - Дніпро: Дніпровський PI НАДУ. - С. 191-199.

7. Бєлай С.В., Бондаренко О.Г. Удосконалення механізмів реагування на кризові ситуації, що загрожують державній безпеці України: розділ монографії за заг. ред. А.С. Нестеренко/ С.В. Бєлай, О.Г. Бондаренко // Процес модернізації системи державного управління: адміністративний, та фінансовий аспекти. - О.: Видавничий дім «Гельветика», 2017 - С. 19-33.

8. Ролін, І.Ф. Зміст основних термінів у сфері логістичного забезпечення військових формувань / I.Ф. Ролін, І.Є. Морозов, О.В. Мінько // Збірник наук. праць ХНУПС. - 2017. - № 1. - Х.: ХНУПС. - С. 61-64.

9. Справочник по тыловому обеспечению НАТО [Електрон. ресурс], 2012. - Режим доступа: https://www.nato.int/nato_static_fl2014/asset s/pdf/pdf_2016_03/20160 303_2012-logistics_hndbk-ru.pdf. 
10. Каличева Н.Є. Роль 11. Каличева Н.Є. Логістичні транспортно-логістичних систем у підходи, як основа раціональної забезпеченні стійкого розвитку економіки організації виробничого процесу на /Н.Є. Каличева// Вісник економіки підприємстві/ Н.Є. Каличева , В.О. транспорту i промисловості: збірник Маслова// Вісник економіки транспорту i наукових праць. - Харків, УкрДУЗТ, 2017 промисловості. Збір наук. праць - Харків, . - № 58 . - С. 103-109.

УкрДАЗТ, 2014. - № 47. - С. 83 - 86.

УДК 368.86

\title{
НЕОБХІДНІСТЬ ТА ЗНАЧЕННЯ КОРИГУЮЧИХ КОЕФІЦІЕНТІВ У СТРАХУВАННІ ЦИВІЛЬНОЇ ВІДПОВІДАЛЬНОСТІ АВТОВЛАСНИКІВ
}

\author{
Кондратенко Д. В., к.е.н, доцент, \\ Гудзь А.В., студентка (ХНУБА)
}

У статті досліджено теоретичні аспекти страхування ичивільної відповідальності автовласників. Визначена законодавча база на якій трунтується обов'язкове страхування ичивільно-правової відповідальності власників транспортних засобів в Україні. Розкрита схема обчислення страхового тарифу та сутність коригуючих коефічієнтів у обов'язковому страхуванні ичивільної відповідальності автовласників. Проаналізовано страховий портфель Харківської обласної дирекиї ПАТ «НАСК «ОРАНТА», отримані страхові преміі за договорами обов'язкового страхування иииільної відповідальності автовласників та здійснені за ними виплати. Визначено рівень збитковості за иими договорами, вплив коригуючих коефіцієнтів на дохідність страхової компанії та запропоновано иляхи вирішення даної проблеми.

Ключові слова: коригуючі коефіцієнти, страхування цивільно-правової відповідальності, обов'язкове страхування, страховий тариф, базовий страховий платіж, страхова премія, страхова виплата, страховий портфель, страховий поліс.

\section{НЕОБХОДИМОСТЬ И ЗНАЧЕНИЕ КОРРЕКТИРУЮЩИХ КОЭФИЦИЕНТОВ В СТРАХОВАНИИ ГРАЖДАНСКОЙ ОТВЕТСТВЕНОСТИ АВТОВЛАДЕЛЬЦЕВ}

\author{
Кондратенко Д. В., к.э.н., доцент, \\ Гудзь А.В., студентка (ХНУСА)
}

В статье исследованы теоретические аспекты страхования гражданской ответственности автовладельиев. Определена законодательная база на которой основывается обязательное страхование гражданско-правовой ответственности владельцев транспортных средств в Украине. Раскрыта схема исчисления страхового тарифа и сущность корректирующих коэффициентов в обязательном страховании гражданской ответственности автовладельцев. Проанализировань страховой

(C) Кондратенко Д.В., Грудзь А.В.
Вісник економіки транспорту і промисловості № 61, 2018 